\title{
4. SEISMIC STRATIGRAPHY OF THE NORTH AOBA BASIN, CENTRAL NEW HEBRIDES ISLAND ARC ${ }^{1}$
}

\author{
Michael A. Fisher, ${ }^{2}$ H. Gary Greene, ${ }^{2}$ Eric L. Geist, ${ }^{2}$ Jean-Yves Collot ${ }^{3}$
}

\begin{abstract}
Drilling at Sites 832 and 833 in the intra-arc North Aoba Basin sampled an uppermost Miocene but primarily Pliocene and younger section. Many of the lithostratigraphic units identified correlate with events in seismic reflection data. Although the complex geology within this basin makes it difficult to extend detailed stratigraphy far from the drill sites, general aspects of the onshore and offshore stratigraphy are similar. For example. Pliocene carbonate-rich and relatively volcanic-poor rocks on Espiritu Santo Island are exposed on Maewo Island and were penetrated at both sites. These rocks produce a highly diverse reflection signature, which varies from poor reflections to high-amplitude parallel reflections. A major angular unconformity evident in seismic reflection data was one of the main targets of drilling; the unconformity dates from the early Pleistocene. Pleistocene volcanic sediment sampled in the shallowest part of the holes correlates temporally with volcanism along the active volcanic arc. Some of the strong reflections from these rocks stem from interbedded carbonate-rich and volcanic-rich layers. Reefs evident in offshore rocks indicate long-term submergence of the area east of Espiritu Santo Island. Seismic data show that below the deepest drilled rocks at Site 832 the basin fill includes primarily a channeled-fan complex that thins markedly into the basin and was probably derived during late Miocene erosion of Espiritu Santo Island.
\end{abstract}

\section{INTRODUCTION}

The large, active volcano on Aoba Island separates the intra-arc Aoba Basin into northern and southern parts that straddle the presently active volcanic arc. This report concerns the stratigraphy of the northern part of the basin, which is rimmed by islands and relatively shallow-water $(<2000 \mathrm{~m})$ summit areas of the New Hebrides Island Arc (Fig. 1). Clockwise around the basin, beginning in the west, are the main islands of Espiritu Santo, Santa Maria, Maewo, and Aoba. Drilling in this basin during Leg 134 took place at Sites 832 and 833, which are located on or near the deep-water (about $3000 \mathrm{~m}$ ) basin plain. Drilling at these sites was expected to reveal when the collision between an aseismic ridge and the New Hebrides Island Arc gained sufficient intensity to affect the intra-arc North Aoba Basin and when a proposed reversal in subduction polarity took place. The main purpose of this report is to correlate the onshore and offshore stratigraphy with events in seismic reflection data. Previous studies have already described the main aspects of the basin stratigraphy and structure (Carney and Macfarlane, 1978, 1980, 1982; Fisher et al., 1988; Greene et al., 1988; Katz, 1988; Macfarlane et al., 1988). The new insight into basin stratigraphy and evolution reported here stems from drilling data and from reprocessing of seismic reflection data.

Twenty-four-fold multichannel seismic reflection data used to prepare this report were collected during two cruises of the U.S. Geological Survey (USGS) ship, the S.P. Lee (1982 and 1984), and one cruise of the French research vessel, the Jean Charcot (1987). Data from the S.P. Lee were collected using an airgun array, and data from the Jean Charcot were collected using Flexichoc (Collot et al., this volume). Data from the three cruises were processed using DISCO software (trademark Cogniseis Development, Inc.) at the USGS in Menlo Park, CA.

Greene, H.G., Collot, J.-Y., Stokking, L.B., et al., 1994. Proc. ODP. Sci. Results. 134: College Station, TX (Ocean Drilling Program).

${ }^{2}$ U.S. Geological Survey, 345 Middlefield Rd., MS 999. Menlo Park, CA 94025. U.S.A. France.

\section{Onshore Stratigraphy}

The description of the onshore stratigraphy presented here is summarized from Carney and Macfarlane (1982) and Macfarlane et al. (1988). The stratigraphy most important to understanding the drilling results is exposed on Espiritu Santo and Maewo islands (Figs. 1 and 2), which lie along the west and east sides of the basin, respectively. Intense volcanism on Espiritu Santo Island during the late Oligocene through middle Miocene is recorded in coarse andesitic and basaltic breccias, lava flows, graywacke, and coarse reef debris. Rocks of this age were derived from a landmass north or northwest of the island. The lower part of these rocks is locally calcareous, including large displaced blocks of reef limestone, whereas the upper part is richly volcaniclastic sandstone, graywacke, and massive conglomerate. The displaced reef blocks extend for several kilometers and are as thick as $1 \mathrm{~km}$. These blocks suggest an important stratigraphic process that involves slumping of large reef masses into deep-water areas, and we use this concept to help interpret the cause of local zones of chaotic seismic reflections from within the North Aoba Basin. Rocks of middle Miocene age include graywacke and breccia, and the upper part of this sequence is calcarenite and calcilutite that lacks a major volcanic component. Lower and middle Miocene basaltic, andesitic, and minor gabbroic intrusive rocks crosscut middle Miocene and older rocks. Regional uplift and erosion at the end of the middle Miocene was followed by deposition of transgressive uppermost Miocene and lower Pliocene rocks, primarily hemipelagic calcarenite, that are now confined to the central part of the island. This unconformity is coeval with the $180 \mathrm{~m}$ or greater late Miocene eustatic sea-level lowering, which was quantified from reefs preserved in northeastern Australia (Pigram et al., 1992). Upper Pliocene to lower Pleistocene rocks on Espiritu Santo Island have restricted distribution and are bounded below by an unconformity; they include primarily siltstone, but conglomerate is also present.

Rocks exposed on Maewo Island are not as old as late Oligocene; however, ophiolite of this age is exposed to the south on Pentecost Island, so similar-aged rocks might underlie Maewo Island. The oldest exposed rocks on Maewo Island are lower but primarily middle Miocene turbidite and debris-flow deposits that include tuffaceous siltstone, sandstone, and subordinate conglomerate, breccia, and calcarenite. The upper Miocene sequence includes foraminiferal mudstones that were deposited under $2-3 \mathrm{~km}$ of quiet water. In fact, most 


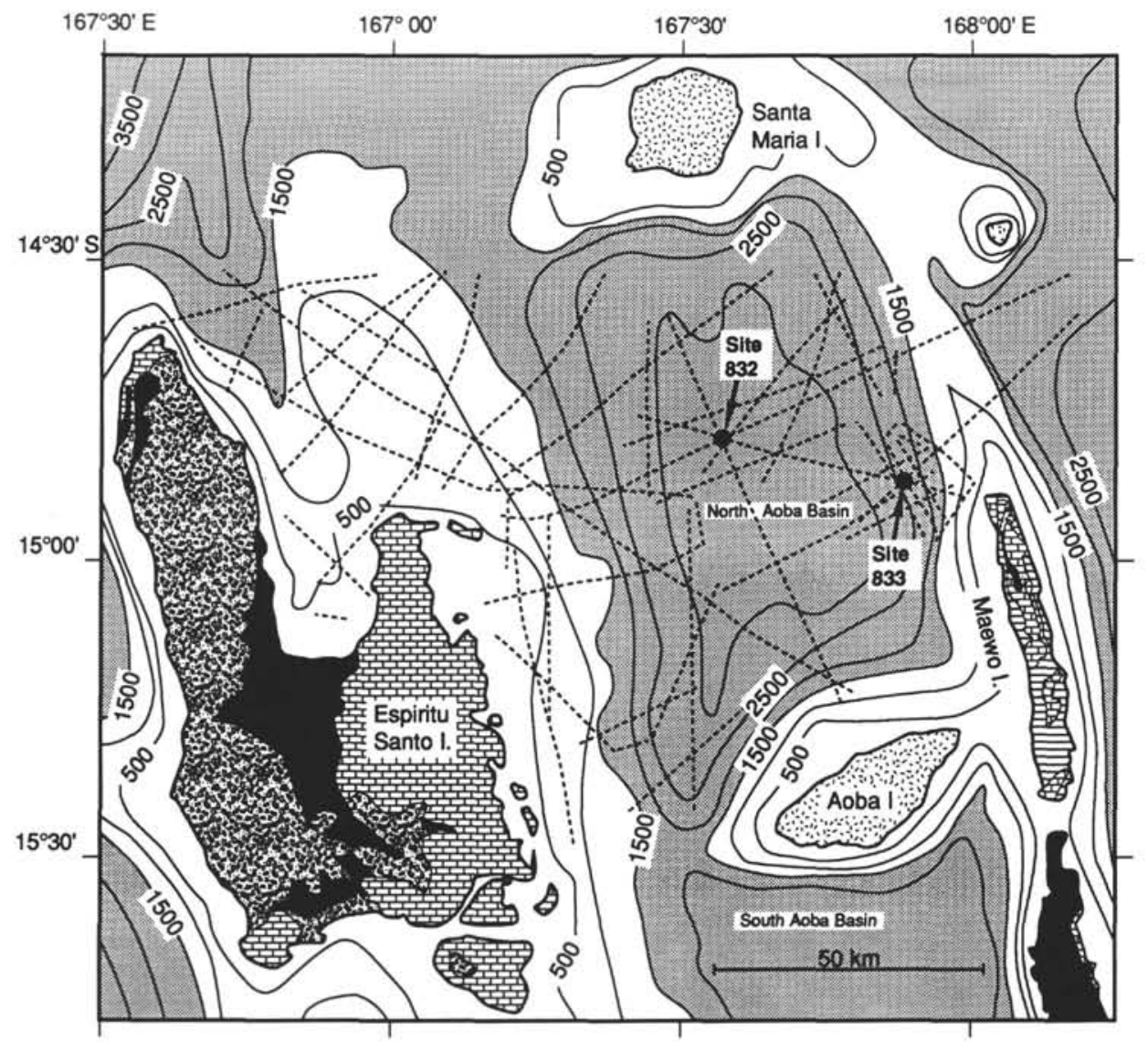

Figure 1. A. Geology and geography of the North Aoba Basin, Vanuatu, showing Sites 832 and 833, as well as tracklines of multichannel seismic data (dashed lines). Geology is summarized from Macfarlane et al. (1988) and Carney and Macfarlane (1982). Bathymetry in meters. Medium gray shading in offshore areas show where water is deeper than $1500 \mathrm{~m}$. B. Locations of seismic reflection sections are shown in figures in this report. Heavy black line segments show section locations, and bold numbers refer to the number of the figure. Bathymetry in meters. Medium-gray shading in offshore areas show where water is deeper than $1500 \mathrm{~m}$. Dashed lines show tracklines of multichannel seismic reflection data.

of the Miocene sequence on this island indicates a temporally decreasing energy in the depositional environment. The middle late Miocene through late Pliocene, however, saw voluminous extrusion of submarine lava that formed pillows of basalt, picrite, and basaltic andesite. After the volcanic activity waned, lower to upper Pliocene foraminiferal mudstone was deposited and records a return to quiet deposition. In the earliest late Pliocene, Maewo Island emerged and was eroded; the erosion surface was subsequently buried so that rocks of later Pliocene and Pleistocene age include microfossil-rich sandstone and mudstones deposited in quiet water.

On both Espiritu Santo and Maewo islands, upper Pleistocene to Holocene rocks include primarily reef limestone. The Holocene reefs are exposed in terraces that record uplift of both the western and eastern basin flanks. The Santa Maria and massive Aoba volcanoes border the North Aoba Basin on the north and south, respectively, and they expose uppermost Pliocene (Santa Maria only) and Quaternary (both volcanoes) volcanic rocks. However, the age of the oldest rocks that form the cores of these volcanoes is not known.

\section{BASIN STRATIGRAPHY FROM DRILLING AND CORRELATION WITH ONSHORE ROCKS}

\section{Stratigraphy at Site 832}

Site 832 was drilled approximately $50 \mathrm{~km}$ east of Espiritu Santo Island (Fig. 1); this site lies near the western limit of the flat basin plain where the water depth is $3 \mathrm{~km}$. The deepest rocks penetrated are basaltic breccia, conglomerate, and volcanic sandstone and siltstone, which comprise lithostratigraphic Unit VII. This unit has an uncertain age: microfossils suggest an early to middle Miocene age, but one volcanic clast yields a radiometric age of $5.7 \mathrm{Ma}$ (Rex, this volume). The older age could be correct in that on Espiritu Santo Island lower and middle Miocene rocks are coarse volcanic breccia, graywacke, and limestone that are similar lithologically to the offshore Unit VII. However, rocks overlying the onshore upper Miocene unconformity include fossils reworked from the older rocks (Macfarlane et al., 1988), and such reworking can explain the presence of the lower to middle Miocene microfossils in offshore Unit VII. We propose that the younger age (latest Miocene) is correct (see also Goud Collins, this volume) and that offshore rocks were deposited toward the end of erosion of the major upper Miocene onshore unconformity. Upper Miocene volcanic rocks are exposed on Maewo Island, and upper Miocene andesitic basalt was dredged from the arc slope west of Espiritu Santo Island (Collot et al., 1992). Hence, either Maewo Island was a source for some clasts of volcanic rock that was transported across the basin to Site 832 despite the absence of an upper Miocene unconformity there, or upper Miocene volcanic rocks are present somewhere west of the Aoba Basin.

Lithostratigraphic Unit VI is a volcanic sandstone that is mostly barren of microfossils, but the lowermost part of this unit contains microfossils that indicate a middle to late Miocene age. In view of the young age that others have proposed for the underlying Unit VII, Unit VI can be no older than latest Miocene. A sandstone at the top of Unit VI grades upward into volcanic siltstone that forms the base 


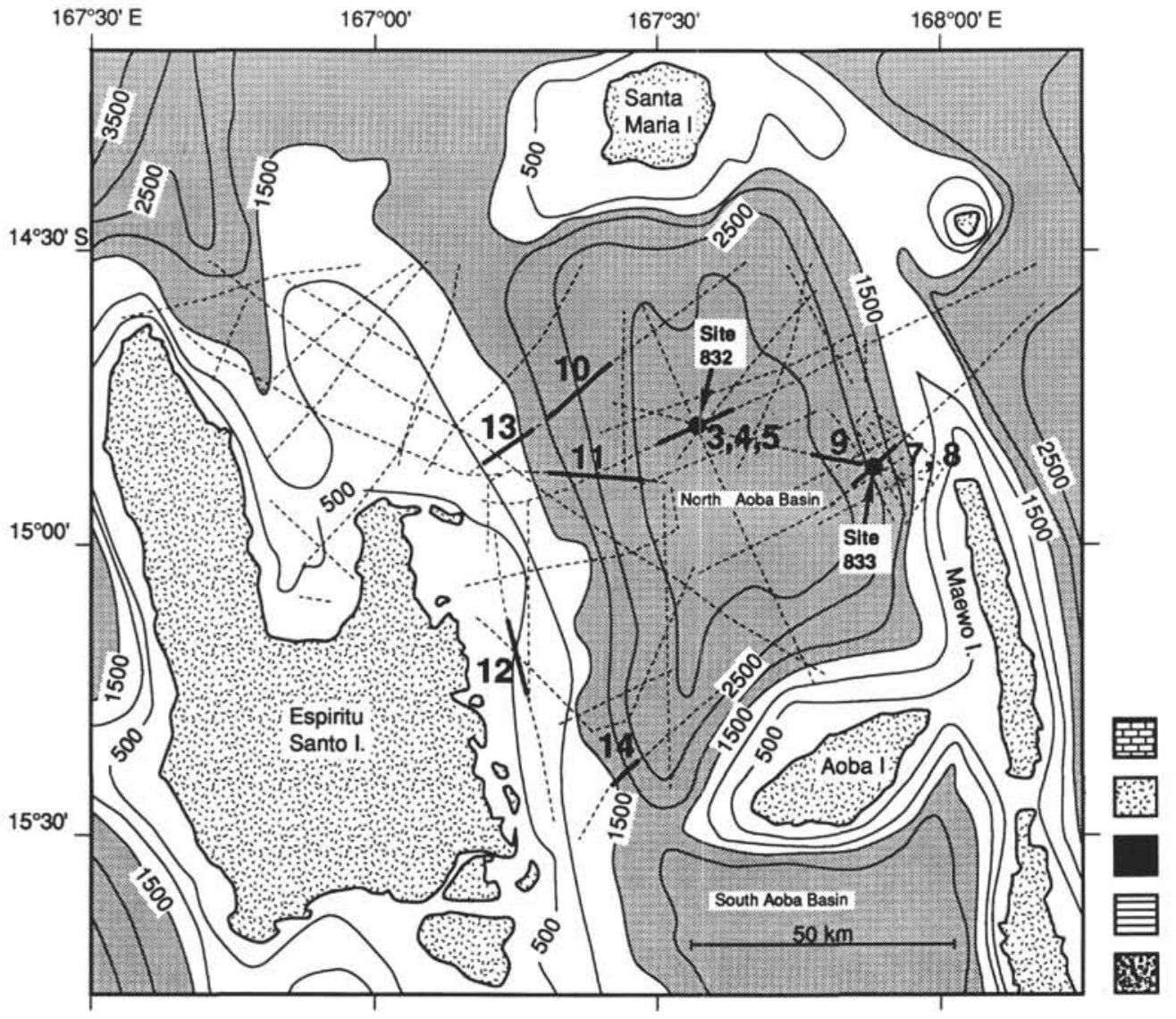

\section{Quaternary limestone and other sediments \\ Quaternary arc volcanic rocks}

Pliocene, and lower Quaternary sedimentary rocks

Middle and upper Miocene volcanic, volcaniclastic and biogenous sedimentary rocks on Maewo I Upper Oligocene through middle Miocene volcaniclastic rocks on Espiritu Santo I.

Figure 1 (continued).

of Unit V, which includes strata of late Miocene to Pliocene age. Most of Unit V, however, includes fine-grained calcareous lithologies. We correlate the limestone of Unit V with the onshore upper Miocene and Pliocene calcilutite that was deposited over the major onshore unconformity. Lithostratigraphic Unit IV includes Pleistocene and/or Pliocene strata; a lithified basalt breccia occurs near its base. The resultant contrast in physical properties between the limestone of Unit V and the breccia of Unit IV strongly expresses itself in all well logs. In particular the sonic and density logs show sharp changes, which means that this contact produces a strong reflection; indeed, synthetic seismograms described below show that this contact correlates with a strong reflection from an angular unconformity evident in seismic reflection data.

Rocks near the upper contact of Unit IV grade into overlying calcareous rocks. This gradation is reflected in the sonic log, which shows a gradual upward velocity decrease over the depth interval from 650 to $600 \mathrm{~m}$. The lower part of Unit III consists of Pleistocene and possibly upper Pliocene, highly calcareous sedimentary rocks, including chalk and limestone. The rest of the unit is volcanic sandstones, siltstone, and breccias, but fine-grained units predominate throughout. Unit II is Pleistocene volcanic sandstone, siltstone, and claystone and is transitional between the more calcareous unit below and the largely volcanic one above. Units III and II correlate with silt, sand, and conglomerate that was deposited on Espiritu Santo Island. Unit $\mathrm{I}$ is Pleistocene and includes unconsolidated volcanic clay, silt, and sand. This unit was deposited while reef limestone accumulated on Espiritu Santo Island.

\section{Stratigraphy at Site $\mathbf{8 3 3}$}

Site 833 is located along the basin flank that rises eastward toward Maewo Island (Fig. 1). The deepest rocks drilled comprise lithostrat- igraphic Unit V, which includes volcanic sandstone of early Pliocene age that was intruded by basalt sills. These sills are dated middle Pliocene (3.3-3.8 Ma; Rex, this volume) and are therefore younger than the upper Miocene and lowermost Pliocene basalt that crops out on Maewo Island (Fig. 2). At the drill site lithostratigraphic Unit IV includes lower to upper Pliocene foraminiferal volcanic siltstone and sandstone, and various calcareous rocks. On Maewo Island Pliocene rocks are similar lithologically to coeval offshore units and consist of foraminiferal mudstone. Offshore the upward transition from lithostratigraphic Unit IV to Unit III is marked by the disappearance of foraminiferal sandstone, which typifies Unit IV, and the appearance of basalt breccia and late Pliocene to possibly early Pleistocene age coarse-grained sandstone, which make up the bulk of Unit III. This rock unit was deposited as an unconformity formed onshore Maewo Island. Unit III and the overlying Unit II are distinguished not only by the reappearance of calcareous rocks in Unit II but also by the wide lithologic variety of this upper unit. The variety encompasses calcareous, volcanic sedimentary rocks, volcanic siltstone, and tuff. The calcareous rocks in Unit II may be contemporaneous with the microfossil-rich sedimentary rocks exposed on Maewo Island. Lithostratigraphic Unit I is upper Pleistocene to Holocene volcanic silt, clay, and vitric ash, whereas reef limestone accumulated during the Pleistocene on Maewo Island.

\section{SYNTHETIC SEISMOGRAMS}

To produce the synthetic seismograms described in this report, we estimated the seismic wavelet produced by our airgun array by modifying a Ricker wavelet to have minimum phase. This wavelet was found to produce synthetic seismograms that match observed data well once the raw seismogram was filtered to have a passband of $8-40 \mathrm{~Hz}$ 


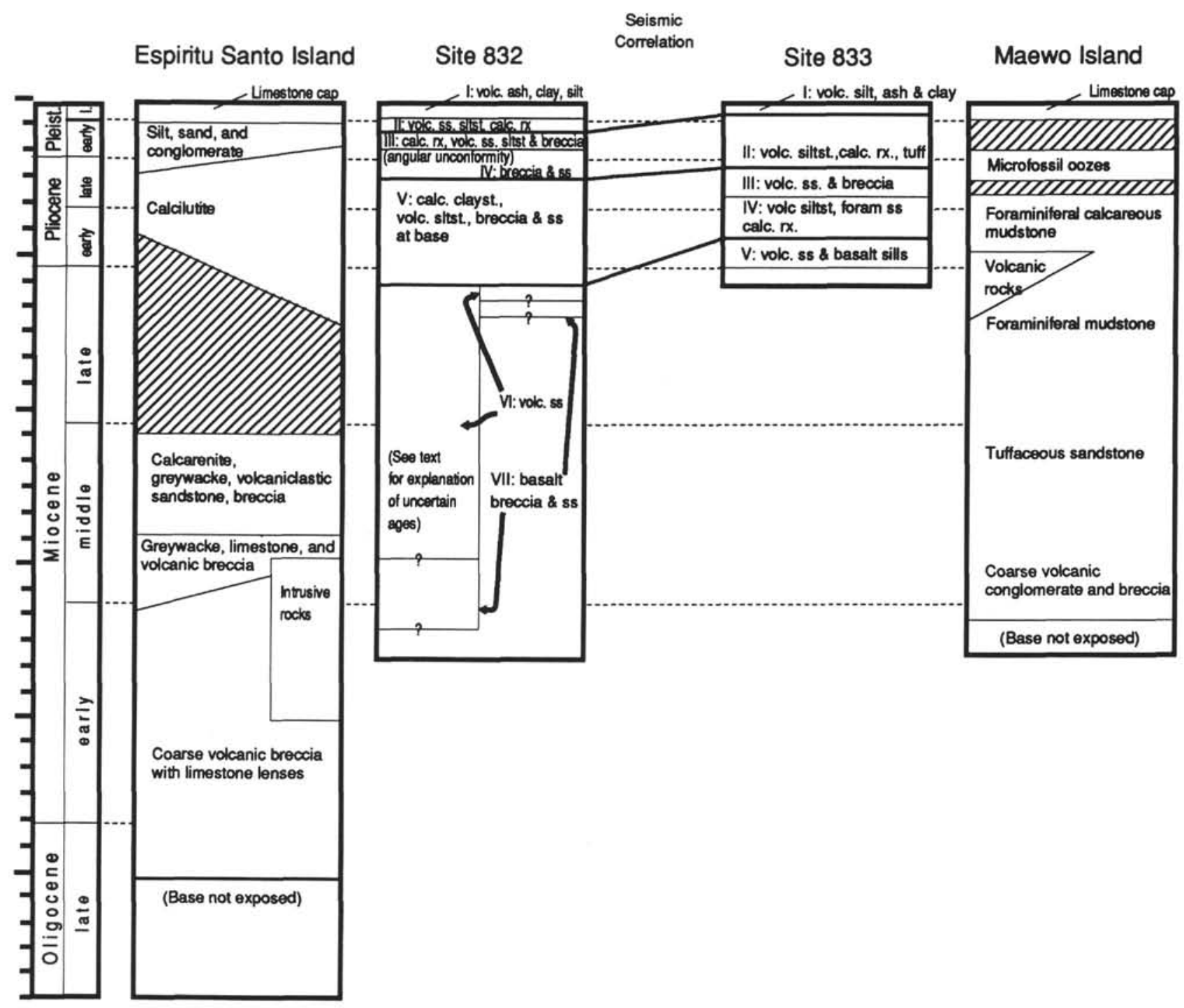

Figure 2. Correlation of onshore stratigraphy, drilling stratigraphy, and seismic stratigraphy across the North Aoba Basin. Onshore stratigraphy is summarized from Macfarlane et al. (1988) and Carney and Macfarlane (1982). Calc. = calcareous, l. = late, Pleist. = Pleistocene, rx. = rocks, ss. = sandstone, sltst. $=$ siltstone, unconf. $=$ unconformity, volc. $=$ volcanics .

to match the power spectrum of the airgun array. We converted the depth dimension of the sonic-log data to traveltime and resampled the converted log. Through testing we determined that the density computed from a generalized velocity-density relationship gave the best correlation between observed and synthetic seismic data.

\section{Site 832}

Only a partial synthetic seismogram could be calculated for Site 832 because the upper part of the drill hole was unstable; consequently, the drill pipe was left in the hole and no sonic data could be obtained above 280 mbsf. Absence of data from the shallowest part of the basin fill introduces uncertainty into the correlation between observed and synthetic seismic data because accurate traveltimes could not be calculated. Velocities from physical properties measurements were used to approximate the traveltime through the unlogged section.

The synthetic seismogram for Site 832 shows moderate-amplitude reflections at about $0.8 \mathrm{~s}$, near the contact between lithostratigraphic Unit VII, a volcanic breccia and conglomerate, and Unit VI, a volcanic sandstone (Fig. 3). The strong synthetic reflections are caused by a thin rock interval that the sonic log shows to have sharply reduced velocity, but the caliper log shows a coincident narrowing of the hole, which may distort the true magnitude of the velocity change. Since observed seismic reflections do not show a strong reflection near the traveltime of $5.0 \mathrm{~s}$ (Figs. 4 and 5), we think that the borehole narrowing affects the sonic log and creates a spurious synthetic reflection. The contact between lithostratigraphic Unit VI and the overlying Unit $\mathrm{V}$, a limestone, causes little variation in the sonic log, and the weak synthetic reflections simulate the weak, observed reflections. For example, a low-amplitude, low-frequency event at about $0.7 \mathrm{~s}$ on the synthetic seismogram (Fig. 3) is similar to observed reflections at about 4.9 s (Figs. 4 and 5), indicating that the calcareous rocks are only weakly reflective and have a transitional contact with the underlying volcaniclastic rocks.

The strongest synthetic reflection from near mid-depth in Hole $832 \mathrm{~B}$ occurs at a traveltime of about $0.61 \mathrm{~s}$ and marks the contact between the limestone of Unit $\mathrm{V}$ and the overlying breccia and sandstone of Unit IV (Fig. 3). This synthetic reflection correlates with a strong observed reflection at $4.8 \mathrm{~s}$ (Figs. 4 and 5). Figure 5 shows that west of the drill site the observed reflection consists of a single 


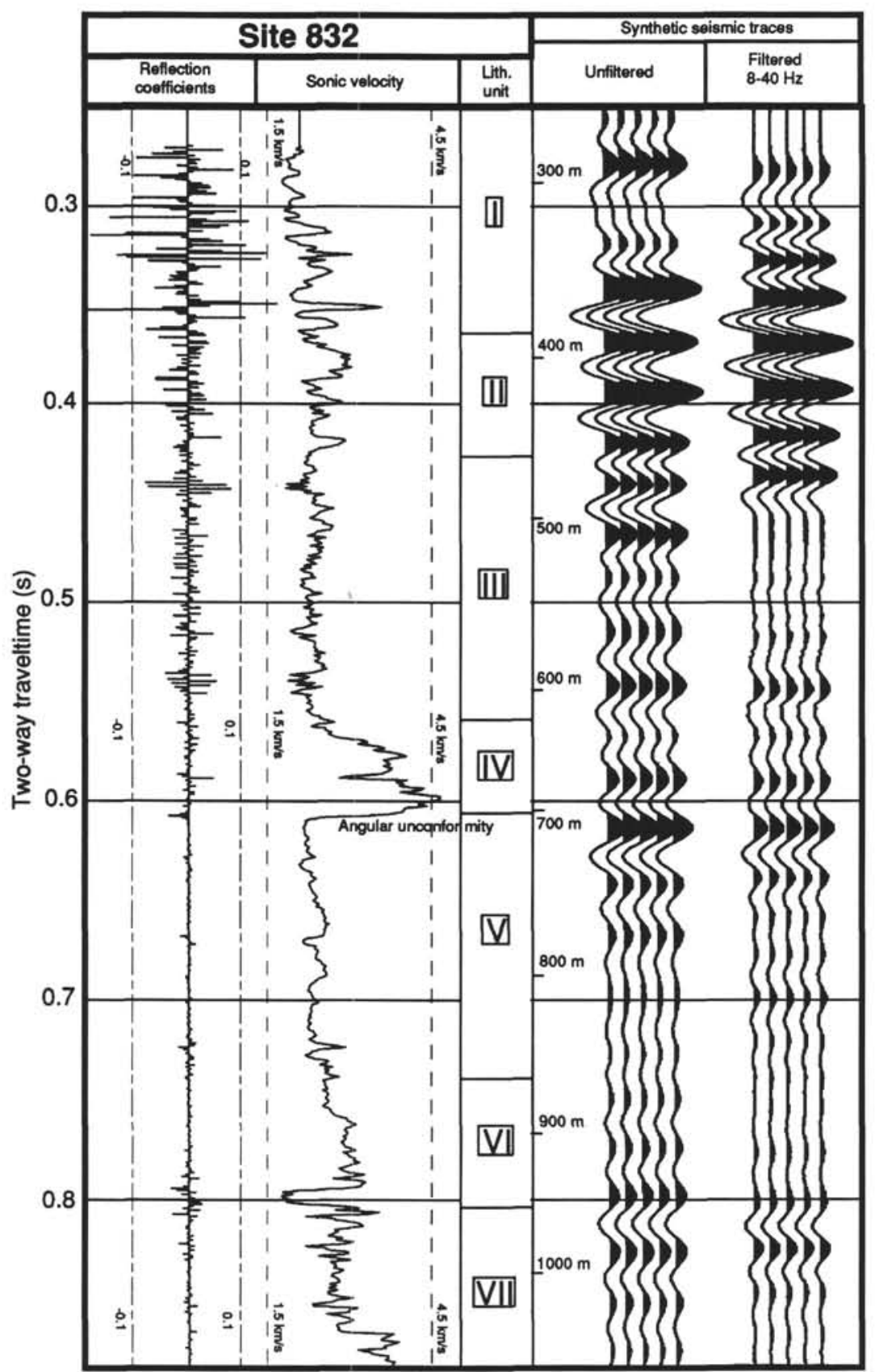

Figure 3. Synthetic seismograms derived from sonic and density data from Site 832. Also shown are reflection coefficients and the lithology from drill cores. Location shown in Figure 1B.

high-amplitude peak, but at the site the single peak splits, and the two resultant peaks spread to the east. This correlation between drilling and seismic reflection data is crucial to the tectonic interpretation of the North Aoba Basin because the correlation means that a prominent angular unconformity evident in the seismic reflection data comes from the contact between the limestone of Unit V and the breccia and sandstone of Unit IV. Hence, this offshore unconformity is upper Pliocene or lower Pleistocene, substantially younger than the major upper Miocene unconformity that is exposed on Espiritu Santo Island. However, the offshore unconformity appears to correlate with the unconformity that forms the base of Pleistocene silt, sand, and conglomerate on this island (Fig. 2).

The contact between the breccia and sandstone of Unit IV and the overlying calcareous rocks of Unit III juxtaposes lithologies that are similar to those at the strongly reflective base of Unit IV; despite this similarity the upper contact produces no strong synthetic reflection (Fig. 3). The apparent explanation for the low reflectivity is the transitional change in physical properties at the upper contact. This transition, evident in well logs, agrees with the gradual change in lithology described from cores. The gradation in physical properties makes the upper contact a second-order reflector. Lithostratigraphic Unit III is highly calcareous with a subsidiary volcanic component, and the sonic log shows mainly low-amplitude velocity variations. In partial agreement with the character of the observed seismic data, the synthetic seismogram shows mainly low-amplitude reflections, but local synthetic-reflection peaks do not match the observed data well (Figs. 3 and 4).

The synthetic seismogram shows that the contact between lithostratigraphic Units III and II and the one between Units II and I are masked by strong synthetic reflections that span completely across 


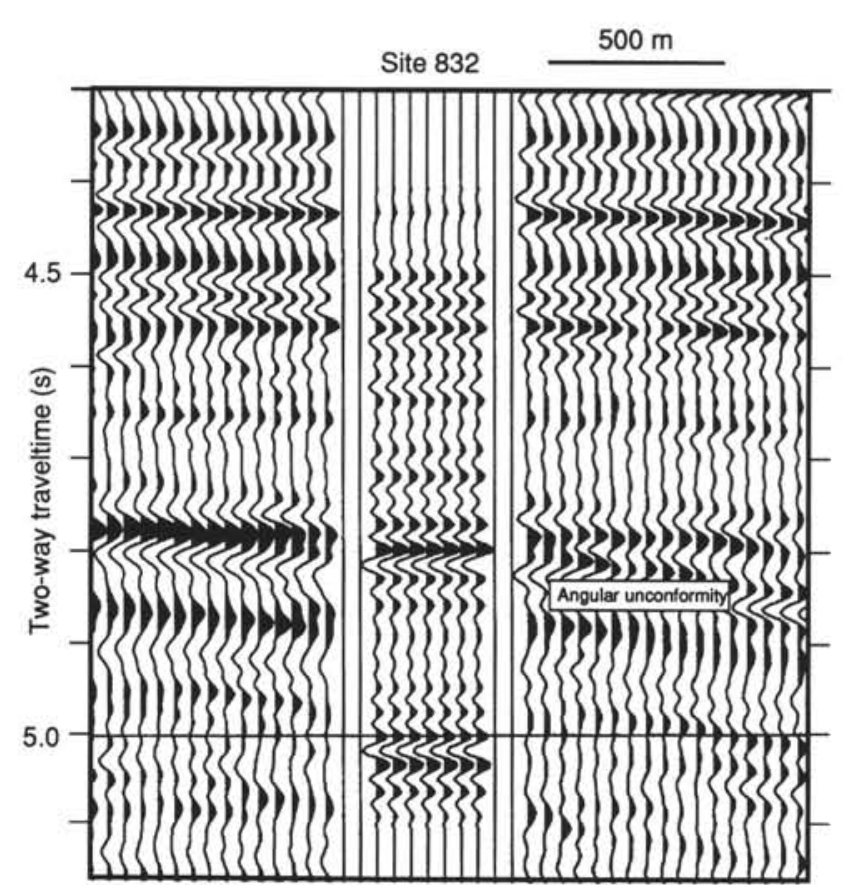

Figure 4. Detailed comparison of observed and synthetic seismograms from Site 832. Seismic data from line 19 are migrated and shown with relative amplitude. Location shown in Figure IB.

Unit II (Fig. 3). This unit includes rocks that mark the upward transition from the calcareous Unit III to the volcanic Unit I, and this lithologic variability causes wide swings in the sonic log and the consequent strong synthetic reflections. The strong synthetic reflections match the observed seismic data well (Fig. 4). Because these observed reflections mask the actual unit contacts, we can interpret only the approximate base of the transitional Unit II by following the base of the strong reflections.

\section{Site 833}

Interbedded sandstone and basalt sills of lithostratigraphic Unit V near the bottom of Hole $833 \mathrm{~B}$ do not produce strong synthetic reflections because these lithologies occur at the very base of the logged interval, and the length of the airgun wavelet means that the expected reflections would occur off the bottom of the seismogram (Fig. 6). Nevertheless, we think that strong synthetic reflections would have been produced by this lithologic variation; this concept is buttressed by strong reflections that are actually observed at $4.35 \mathrm{~s}$ (Fig. 7) and at $4.1 \mathrm{~s}$ (Fig. 8). (The difference in traveltimes evident in these two figures results because seismic data shown in Figure 7 were flattened on the strong event at $4.02 \mathrm{~s}$ to facilitate the correlation between synthetic and observed seismic data.)

Lithostratigraphic Unit IV includes mainly volcanic siltstone and sandstone that produce only isolated reflection peaks. This signature matches the observed reflection data from the lower part of this unit, but synthetic reflections from the upper part of the unit appear to be too strong to match the observed data (Figs. 7 and 8).

The strong synthetic reflection at $0.42 \mathrm{~s}$ matches a strong observed event at $4.0 \mathrm{~s}$, shown in Figure 7, and at $3.7 \mathrm{~s}$, shown in Figure 8. These events stem from the interbedded volcanic sandstone and breccia of lithostratigraphic Unit III. The deep trough in the synthetic seismogram at $0.42 \mathrm{~s}$ (Fig. 6) stems from rocks just below the contact between the coarse-grained rocks of Unit III and the overlying finegrained volcanic siltstone and calcareous rocks of Unit II. Hence this trough can be followed as an approximate marker between these units. Strong synthetic reflections above this contact stem from the rocks of Unit II, and strong observed reflections from just below the sea bottom are from the interbedded volcanic silt, ash, and clay of Unit I (Fig. 8). As at Site 832, an unstable shallow rock section precluded our logging the entire thickness of drilled rocks.

\section{DISCUSSION AND CONCLUSION: SEISMIC STRATIGRAPHY OF THE NORTH AOBA BASIN}

\section{Seismic Stratigraphic Correlation Across the Basin}

Seismic line 1041 connects Sites 832 and 833 (Fig. 1), making possible a generalized correlation of lithostratigraphic units across the

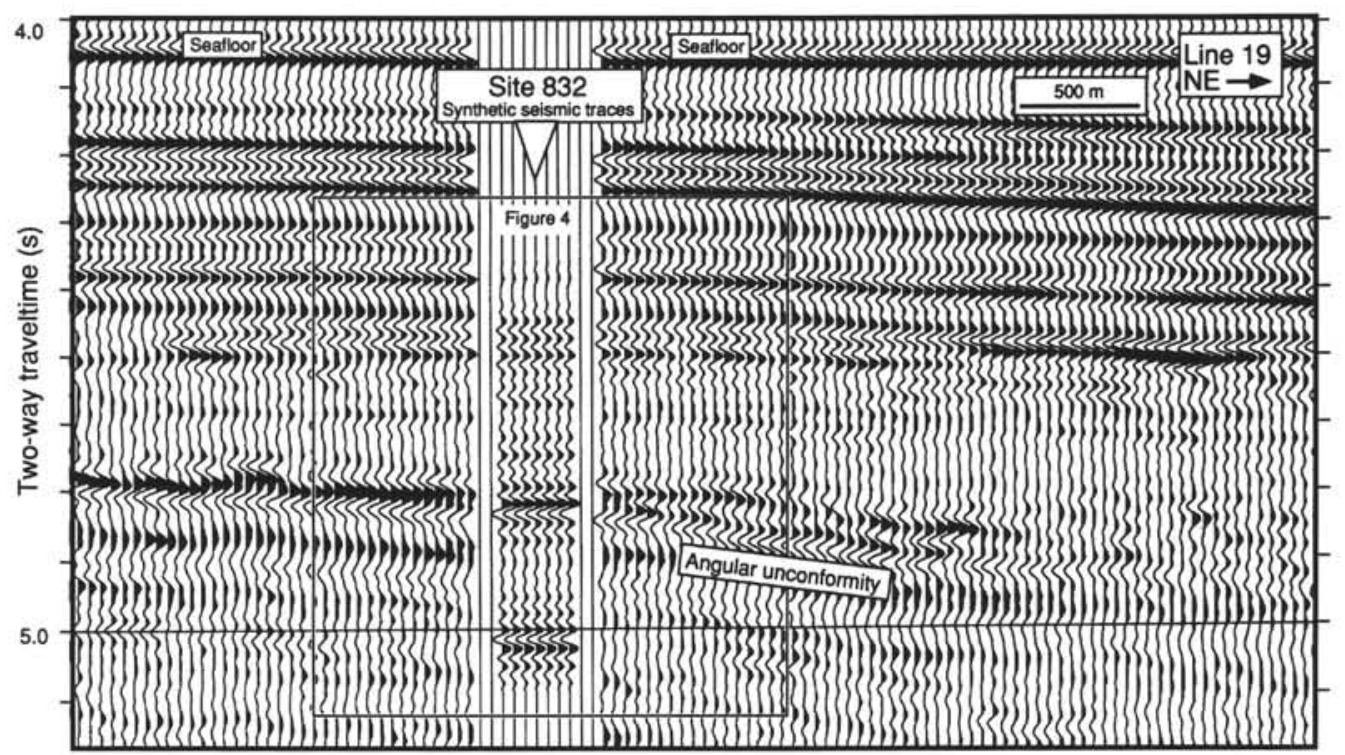

Figure 5. Correlation of the synthetic seismogram from Site 832 with multichannel seismic reflection data. Seismic data from line 19 are migrated and shown with relative amplitude. Location shown in Figure 1B. 


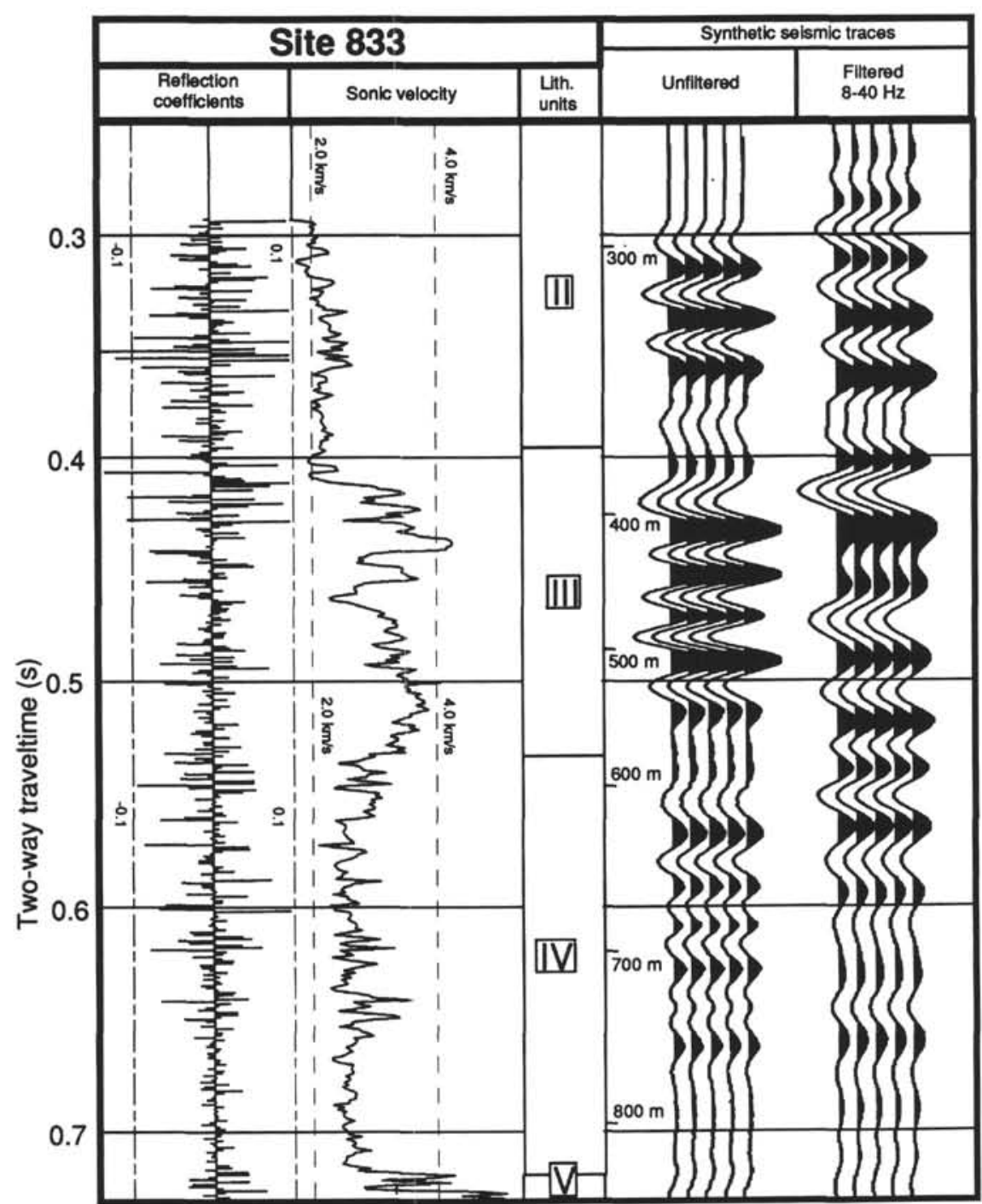

Figure 6. Synthetic seismogram from Site 833 . Also shown are reflection coefficients and the lithology from drill cores. Location shown in Figure 1B. Lith. = lithostratigraphic.

North Aoba Basin. As discussed above, Units I and II in Hole 832B cannot be distinguished seismically because of overlapping reflections, but it appears that both of these units correlate with Unit I at Site 833. In Hole 832 calcareous and volcanic rocks of lithostratigraphic Units III and IV, which overlie the angular unconformity, correlate with the volcanic rocks in Unit II recovered at Site 833. Correlation of lithostratigraphic units in this middle part of both holes, however, is difficult because of complicated seismic stratigraphy. For example, seismic data show two nearly vertical boundaries in acoustic signature from these rocks (Fig. 9). These boundaries reveal high-frequency well-bedded units on their east sides, but on the west, the reflections suggest chaotic bedding. Seismic correlation through highly variable data like these is uncertain, and why the acoustic facies change along nearly vertical boundaries is not easily explained. The boundaries, however, might reveal headwall scarps of slump deposits that return the chaotic reflections from the west side of each boundary. Alternatively, the boundaries might be lateral facies changes within a channeled-fan complex.

Rock units below the angular unconformity evident near Site 832 (Fig. 5) thin eastward toward Site 833, so individual units cannot be correlated using seismic data, but the hemipelagic Unit V of Site 832 is similar lithologically to Units III and IV of Site 833. Volcaniclastic Units VI and VII recovered from Site 832 probably correlate with the volcanic sandstone and basalt sills in Unit V of Site 833. Despite the thinning of units eastward from Site 832 , a basalt clast from near the bottom of this hole indicates that some sediment was derived from Maewo Island. The strong reflections from the interbedded basalt and sandstone from Site 833 were recorded westward about $12 \mathrm{~km}$ from the site toward the middle of the basin (Fig. 8), but other strong reflections do not occur below the one from near the bottom of the hole, suggesting that the recovered basalt and sandstone are not part of a thick volcanic pile.

\section{Seismic Stratigraphy of Rocks Below the Drilled Strata}

Below the western slope that leads from Espiritu Santo Island downward to the basin plain are rock units that thin toward the basin and underlie rocks drilled at Site 832. Seismic reflection data obtained over this slope show that channels were cut into these underlying rocks and the lower parts of some of these rock units lap downward and thin toward the basin center (Fig. 10). This reflection geometry and the channels indicate that slope rocks and hence rocks under the drilled interval at Site 832 constitute a channeled-fan complex. These rocks were most likely derived from Espiritu Santo Island during erosion of the major upper Miocene unconformity. This interpreted age agrees with drilling data because the oldest rocks penetrated at Site 832 are apparently of latest Miocene age. 


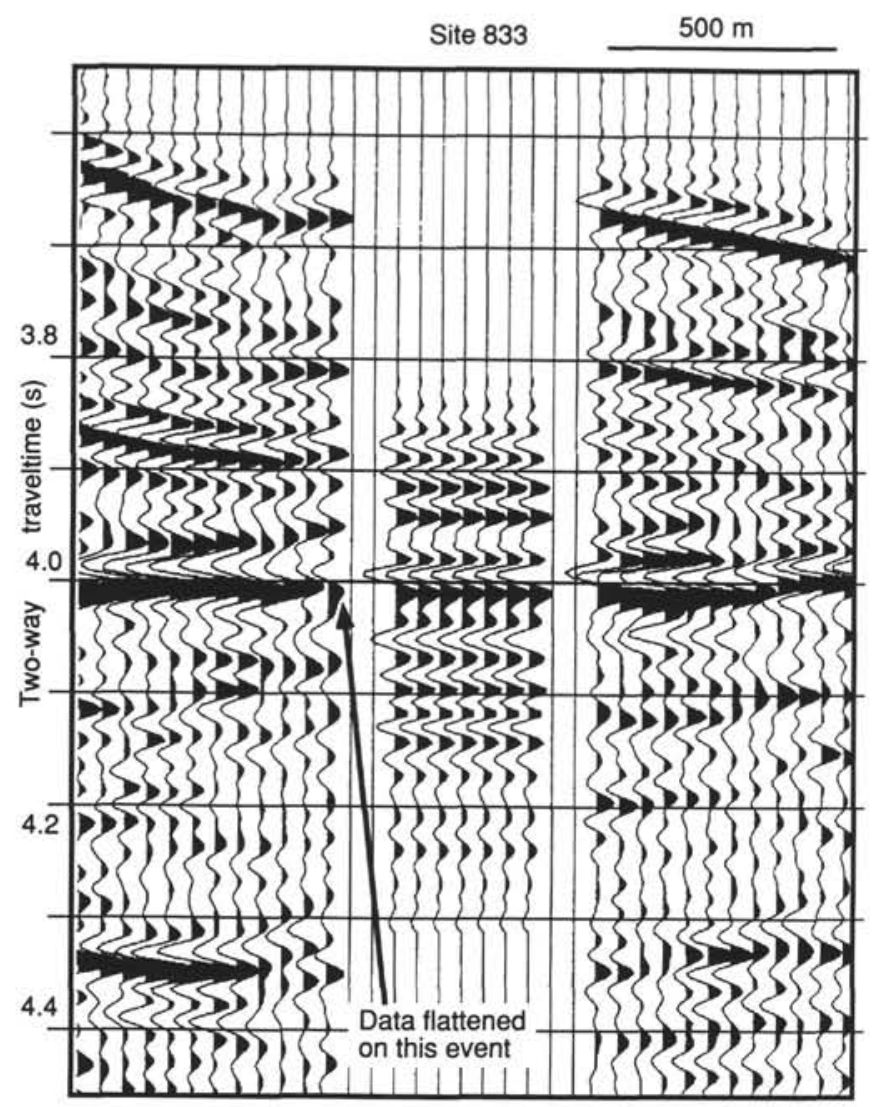

Figure 7. Detailed comparison of observed and synthetic seismograms from Site 833 . Figures 7 and 8 differ in the traveltime to specific seismic events because Figure 7 has been flattened along the black reflection peak just below $4.0 \mathrm{~s}$. Seismic data from line 20 are migrated and shown with relative amplitude. Location shown in Figure 1B.
Channels in the fan complex appear to have their clearest seismic expression in data obtained over the slope northeast of Espiritu Santo Island. Locally these interpreted fans include isolated bodies that return chaotic or no internal reflections. These bodies may include slumped reef rocks; this style of carbonate deposition has been described from the lower Miocene section exposed on Espiritu Santo Island (Macfarlane et al., 1988). Slumped reef masses recognized in seismic reflection data from Nicaragua have been called a megabreccia (Hine et al., 1992). Seismic reflection data from the North Aoba Basin show that slumping is an important depositional process (Greene et al., 1988; Greene and Johnson, 1988; Wong and Greene, 1988); indeed much of the shallow slope deposits along the western basin flank have been mobilized along clearly expressed detachment interfaces (Fig. 11). The seafloor slumps overlie a west-dipping train of relatively high-amplitude discontinuous events (Fig. 11). What this train represents is uncertain: it might reveal a fluid conduit or a thrust fault, both perhaps related to the collision of the d'Entrecasteaux Zone with the central New Hebrides Island Arc. However, offset across this possible fault is not discernible in seismic data.

Hole 833B bottomed in interbedded basalt and sandstone, but these interbedded rocks do not appear to form a thick sequence. Instead, seismic reflection data indicate that reflections from below the hole are similar to those from the sedimentary section. These rocks are probably similar to the upper Miocene section exposed on Maewo Island.

\section{Buried Reefs Near Espiritu Santo Island}

Onshore, Holocene reef terraces indicate that Espiritu Santo Island has been emerging and that the offshore area east of this island may have been submerging (Jouannic et al., 1980; Taylor et al., 1980, 1985, 1987, 1990). Seismic reflection data reveal a submerged reef platform east of this island (Fig. 12; Greene et al., 1988; Wong and Greene, 1988; Katz et al., 1988). The platform is bounded on the east by a reef that is beneath $250 \mathrm{~m}$ of water, and uncommon patch reefs project above the otherwise flat seafloor over the platform. In addition to this reef platform, a probable reef under deeper water $(1200 \mathrm{~m})$ is revealed by detailed processing of seismic reflection data. This reef causes

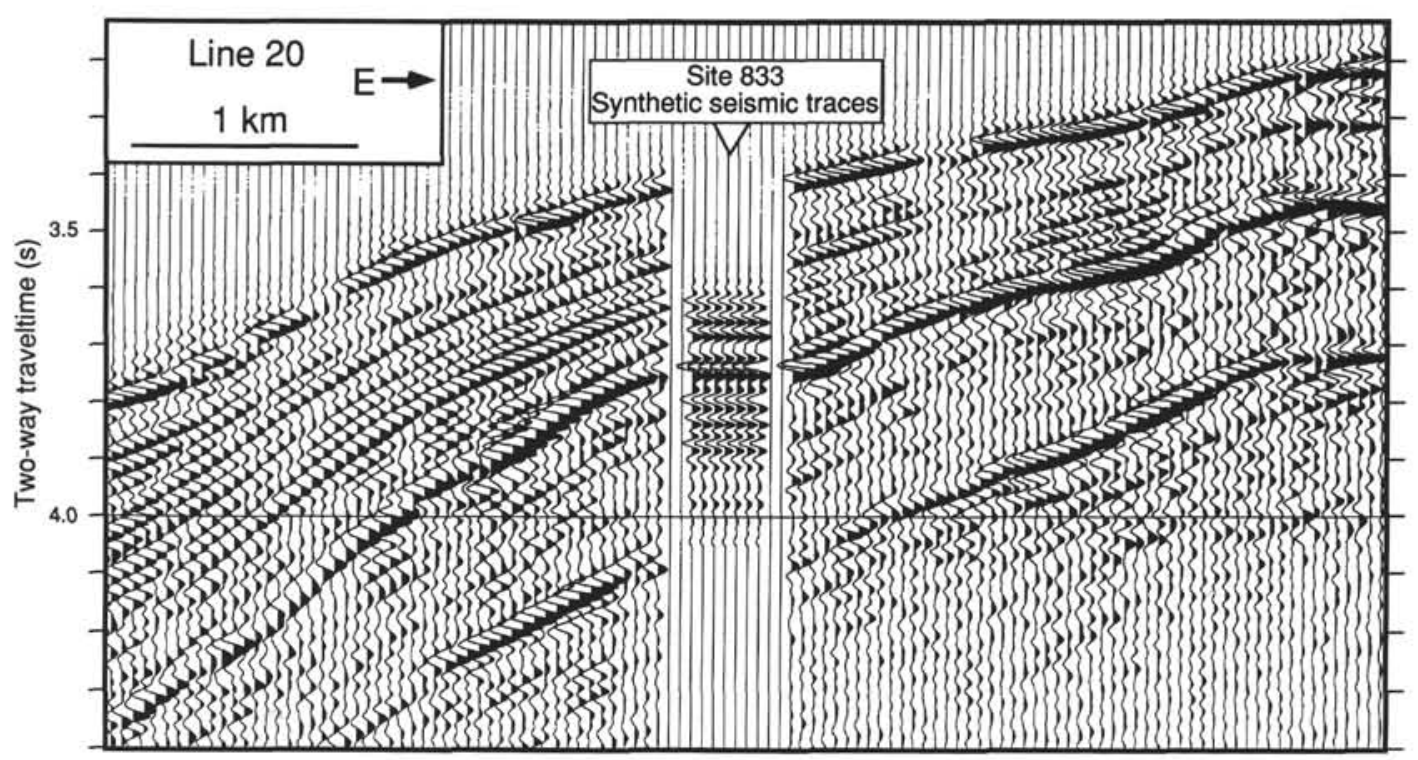

Figure 8. Correlation of the synthetic seismogram from Site 833 with multichannel seismic reflection data. Figures 7 and 8 differ in the traveltime to specific seismic events because Figure 7 has been flattened along the strong reflection at $3.75 \mathrm{~s}$. Seismic data from line 20 are migrated and shown with relative amplitude. Location shown in Figure $1 \mathrm{~B}$. 


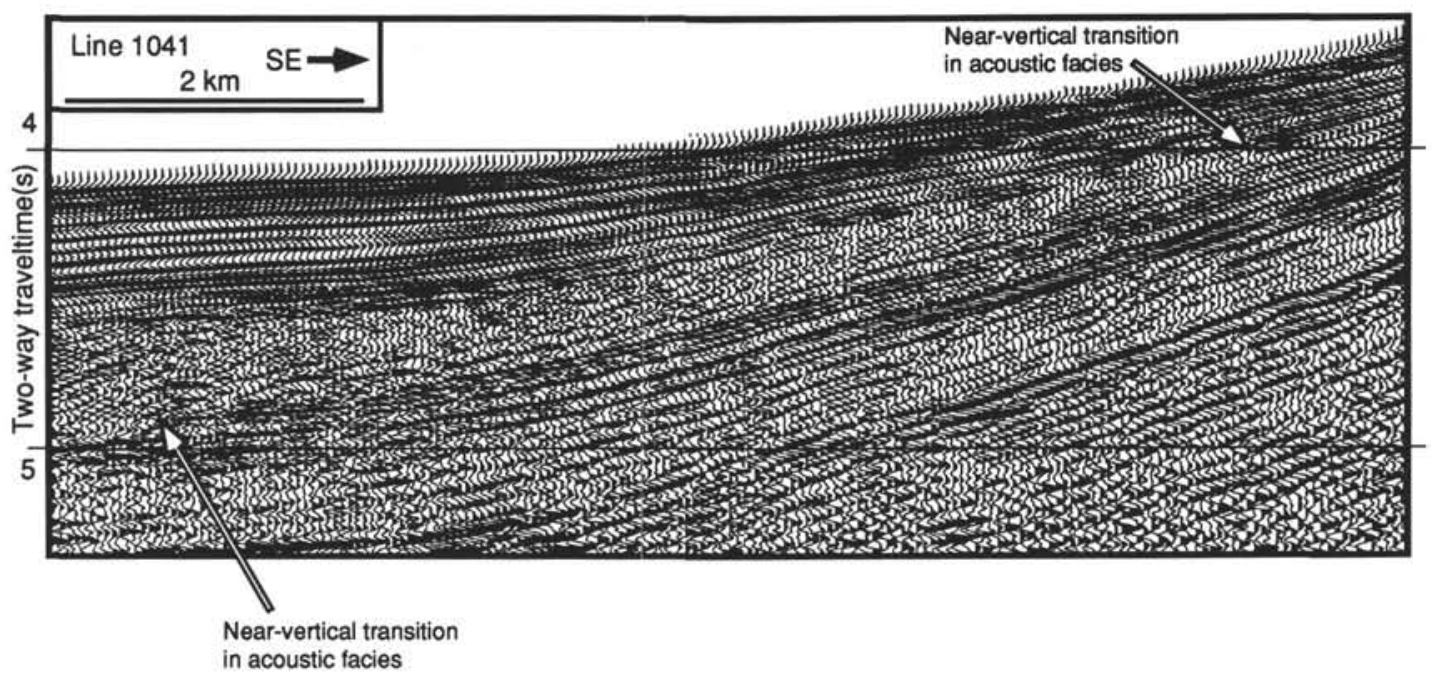

Figure 9. Abrupt changes in acoustic facies along line 1041 that make correlation of individual lithostratigraphic units across the basin difficult. Seismic data are migrated. Location shown in Figure IB.

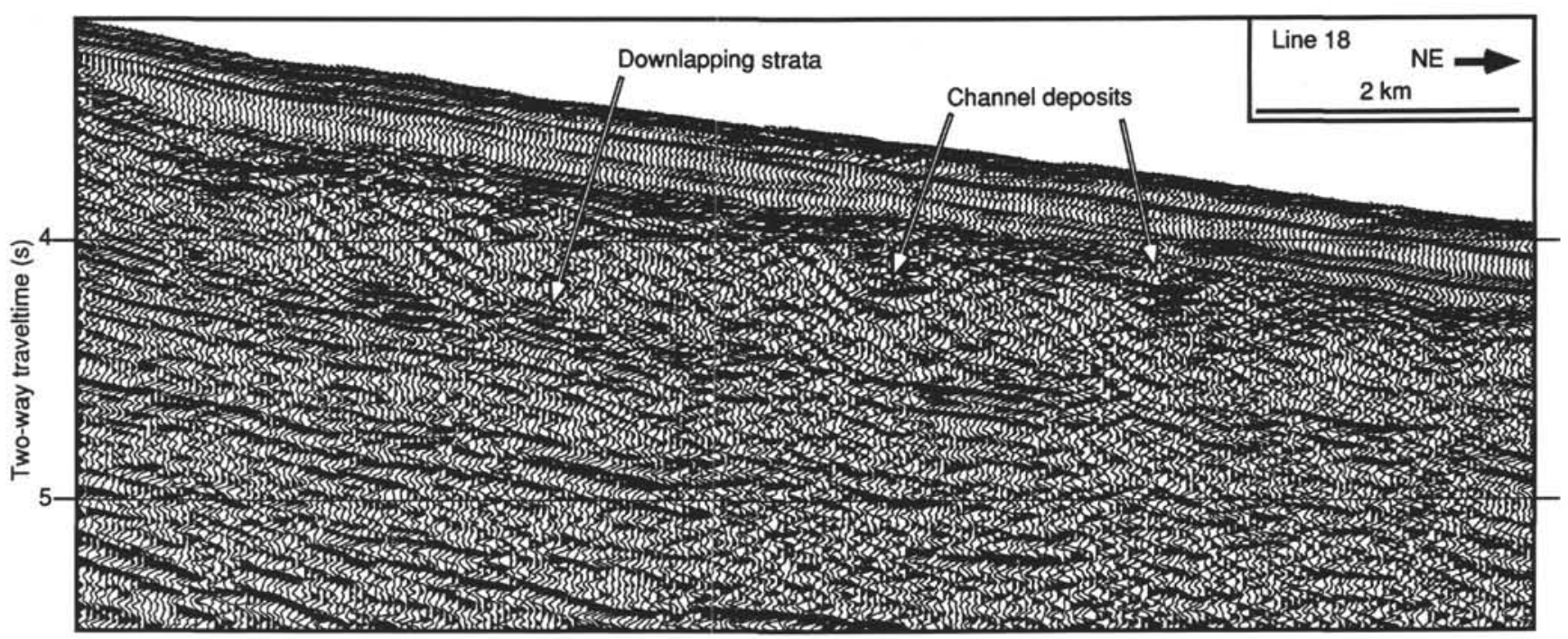

Figure 10. Migrated seismic section from line 18 along the west flank of the North Aoba Basin. The annotated downlapping strata and channel deposits are older than the drilled section at Site 832. This reflection geometry indicates that rocks under the drilled section are a channeled-fan complex. It may have been deposited while a major, upper Miocene unconformity was cut into rocks onshore Espiritu Santo Island. Location shown in Figure IB.

severe velocity distortion of underlying reflectors, such that these reflectors appear like a faulted fold. Migration and depth conversion of seismic data, however, show that a reef lies near the sea bottom and rocks under the reef dip monoclinally toward the basin (Fig. 13). We cannot be sure whether this reef is in place or slumped from shallower areas, but reflections that appear to be from reef talus suggest that the reef is in place. What may be even deeper reefs appear to be encased within slope rocks northeast of Espiritu Santo Island. These possible reefs are expressed in seismic reflection data as zones of poor reflectivity that have an irregular top and commonly have a strongly reflective base (Fig. 14). The possible reef in Figure 14 lies just west of an abrupt downward thickening of the basin fill, which probably reveals the location of an old basin margin. These reflection characteristics are similar to characteristics reported from studies of buried reefs (Bubb and Hatelid, 1978; May and Eyles, 1985; Fontaine et al.,1987; Middleton, 1987; Davis and Jackson, 1988; Anderson et al., 1988, 1989; Erlich et al., 1990; Johnson, 1991; Johnson and Pflueger, 1991; Biddle et al., 1992). If any of the seismically defined reef masses from the North Aoba Basin are in place, they indicate consid- erable $(0.5$ to $2 \mathrm{~km})$ submergence of the island arc. The reef platform east of Espiritu Santo Island (Fig. 12) and the possible buried reef that lies near an old basin margin (Fig. 14) are most likely to be in place, and hence, to be indicators of submergence.

\section{REFERENCES}

Anderson, N.L., Brown, R.J., and Hinds, R.C., 1989, Low- and high-relief Leduc formation reefs: a seismic analysis. Geophysics, 54:1410-1419.

Anderson, N.L., Brown, R.J., Hinds, R.C., and Hills, L.V., 1988. Seismic signature of a Swan Hills (Frasnian) reef reservoir, Snipe Lake Alberta. Geophysics, 53:148-157.

Biddle, K.T., Schlager, W., Rudolph, K.W., and Bush, T.L., 1992. Seismic model of a progradational carbonate platform, Picco di Vallandro, the Dolomites, northern Italy. AAPG Bull., 76:14-30.

\footnotetext{
Abbreviations for names of organizations and publications in ODP reference lists follow the style given in Chemical Abstracts Service Source Index (published by American Chemical Society).
} 
Bubb, J.N., and Hatelid, W.G.. 1978. Seismic stratigraphy and global changes of sea level, Part 10: Seismic recognition of carbonate buildups. AAPG Bull., 62:772-79I

Carney, J.N., and Macfarlane, A., 1978. Lower to middle Miocene sediments on Maewo, New Hebrides, and their relevance to the development of the Outer Melanesian Arc system. Australas. Soc. Explor. Geophys. Bull. 9:123-130.

, 1980. A sedimentary basin in the central New Hebrides Arc. Tech. Bull.-U.N. Econ. Soc. Comm. Asia Pac., Comm. Co-ord. Jt. Prospect Miner. Resour. South Pac. Offshore Areas, 3:109-120.

1982. Geological evidence bearing on the Miocene to Recent structural evolution of the New Hebrides Arc. Tectonophysics, 87:147-175.

Collot, J.-Y, Lallemand, S., Pelletier, B., Eissen, J.-P, Glaçon, G., Fisher, M.A., Greene, H.G., Boulin, J., Daniel, J., and Monzier, M., 1992. Geology of the d'Entrecastaux-New Hebrides island arc collision: results from a deep-sea submersible survey. Tectonophysics, 212:213-241.

Davis, T.L., and Jackson, G.M., 1988. Seismic stratigraphy study of algal mound reservoirs, Patterson and Nancy fields, Paradox basin, San Juan County, Utah. Geophysics, 53:875-880.

Erlich, R.N., Barrett, S.E., and Guo, B.J., 1990. Seismic and geologic characteristics of drowning events on carbonate platforms: AAPG Bull., 74:650.

Fisher, M.A., Falvey, D.A., and Smith, G.L., 1988. Seismic stratigraphy of the summit basins of the New Hebrides Island Arc. In Greene, H.G., and Wong. F.L. (Eds.), Geology and Offshore Resources of Pacific Island ArcsVanuatu Region. Circum-Pac. Counc. Energy and Miner. Resour., Earth Sci. Ser., 8:201-224.

Fontaine, J.M., Cussey, R., Lacaze, J., Lanaud, R., and Yapaudjiam. L., 1987. Seismic interpretation of carbonate depositional environments. AAPG Bull., 71:281-297.

Greene, H.G., and Johnson, D.P., 1988. Geology of the Central Basin region of the New Hebrides Arc inferred from single-channel seismic-reflection data. In Greene, H.G., and Wong, F.L. (Eds.), Geology and Offshore Resources of Pacific Island Arcs-Vanuatu Region. Circum-Pac. Counc. Energy and Miner. Resour., Earth Sci. Ser., 8:177-200.

Greene, H.G., Macfarlane, A., Johnson, D.A., and Crawford, A.J., 1988. Structure and tectonics of the central New Hebrides Arc. In Greene, H.G., and Wong, F.L. (Eds.), Geology and Offshore Resources of Pacific Island Arcs-Vanuatu Region. Circum-Pac. Counc. Energy and Miner. Resour., Earth Sci. Ser., 8:377-412.

Hine, A.C., Locker, S.D., Tedesco, L.P., Mullins, H.T., Hallock, P., Belknap, D.F., Gonzales, J.L., Neumann, A.C., and Snyder, S.W., 1992. Megabreccia shedding from modern, low-relief carbonate platforms, Nicaraguan Rise. Geol. Soc. Am. Bull., 104:928-943.

Johnson, H., 1991. Petroleum geology of Fiji. Mar. Geol., 98:313-352.

Johnson, H., and Pflueger, J., 1991. Potential Mio-Pliocene reef traps in the Iron Bottom basin, Solomon Islands. Mar: Geol., 98:177-186.
Jouannic. C., Taylor, F.W., Bloom, A.L., and Bernat, M., 1980. Late Quaternary uplift history from emerged reef terraces on Santo and Malekula Islands. central New Hebrides island arc. Tech. Bull.-U.N. Econ. Soc. Comm. Asia Pac., CCOP/SOPAC, 3:91-108.

Katz, H.R., 1988. Offshore geology of Vanuatu-previous work. In Greene, H.G., and Wong, F.L. (Eds.), Geology and Offshore Resources of Pacific Island Arcs-Vanuatu Region. Circum-Pac. Counc. Energy and Miner. Resour., Earth Sci. Ser., 8:93-124.

Macfarlane, A., Camey, J.N., Crawford, A.J., and Greene, H.G., 1988. Vanuatua review of the onshore geology. In Greene, H.G., and Wong, F.L. (Eds.), Geology and Offshore Resources of Pacific Island Arcs-Vanuatu Region. Circum-Pac. Counc. Energy and Miner. Resour., Earth Sci. Ser., 8:45-91.

May, J.A., and Eyles, D.R., 1985. Well log and seismic character of Tertiary Terumbu Carbonate, South China Sea, Indonesia. AAPG Bull., 69:13391358.

Middleton, M.F., 1987. Seismic stratigraphy of Devonian reef complexes, northern Canning Basin, western Australia. AAPG Bull., 71:1488-1498.

Pigram, C.J., Davies, P.J., Feary, D.A., and Symonds, P.A., 1992. Absolute magnitude of the second-order middle to late Miocene sea-level fall, Marion Plateau, northeast Australia. Geology, 20:858-862.

Taylor, F.W., Edwards, R.L., Wasserburg, G.J., and Frohlich, C., 1990. Seismic recurrence intervals and timing of aseismic subduction inferred from emerged corals and reefs of the central Vanuatu (New Hebrides) frontal arc. J. Geophys. Res., 95:393-408.

Taylor, F.W., Frohlich, C., Lecolle, J., and Strecker, M., 1987. Analysis of partially emerged corals and reef terraces in the central Vanuatu arc: comparison of contemporary coseismic and nonseismic with Quaternary vertical movements. J. Geophys. Res., 92:4905-4933.

Taylor, F.W., Isacks, B.L., Jouannic, C., Bloom, A.L., and Dubois, J., 1980. Coseismic and Quaternary vertical tectonic movements, Santo and Malekula Islands, New Hebrides island arc. J. Geophys. Res., 85:5367-5381.

Taylor, F.W., Jouannic, C., and Bloom, A.L., 1985. Quaternary uplift of the Torres Islands, northern New Hebrides frontal arc: comparison with Santo and Malekula Islands, central New Hebrides frontal arc. J. Geol., 93:419-438.

Wong, F.L., and Greene, H.G., 1988. Geologic hazards identified in the Central Basin region, Vanuatu. In Greene, H.G., and Wong, F.L. (Eds.), Geology and Offshore Resources of Pacific Island Arcs-Vanuatu Region. CircumPac. Counc. Energy and Miner. Resour., Earth Sci. Ser., 8:225-254.

Date of initial receipt: 17 August 1992

Date of acceptance: 8 March 1993

Ms 134SR-004

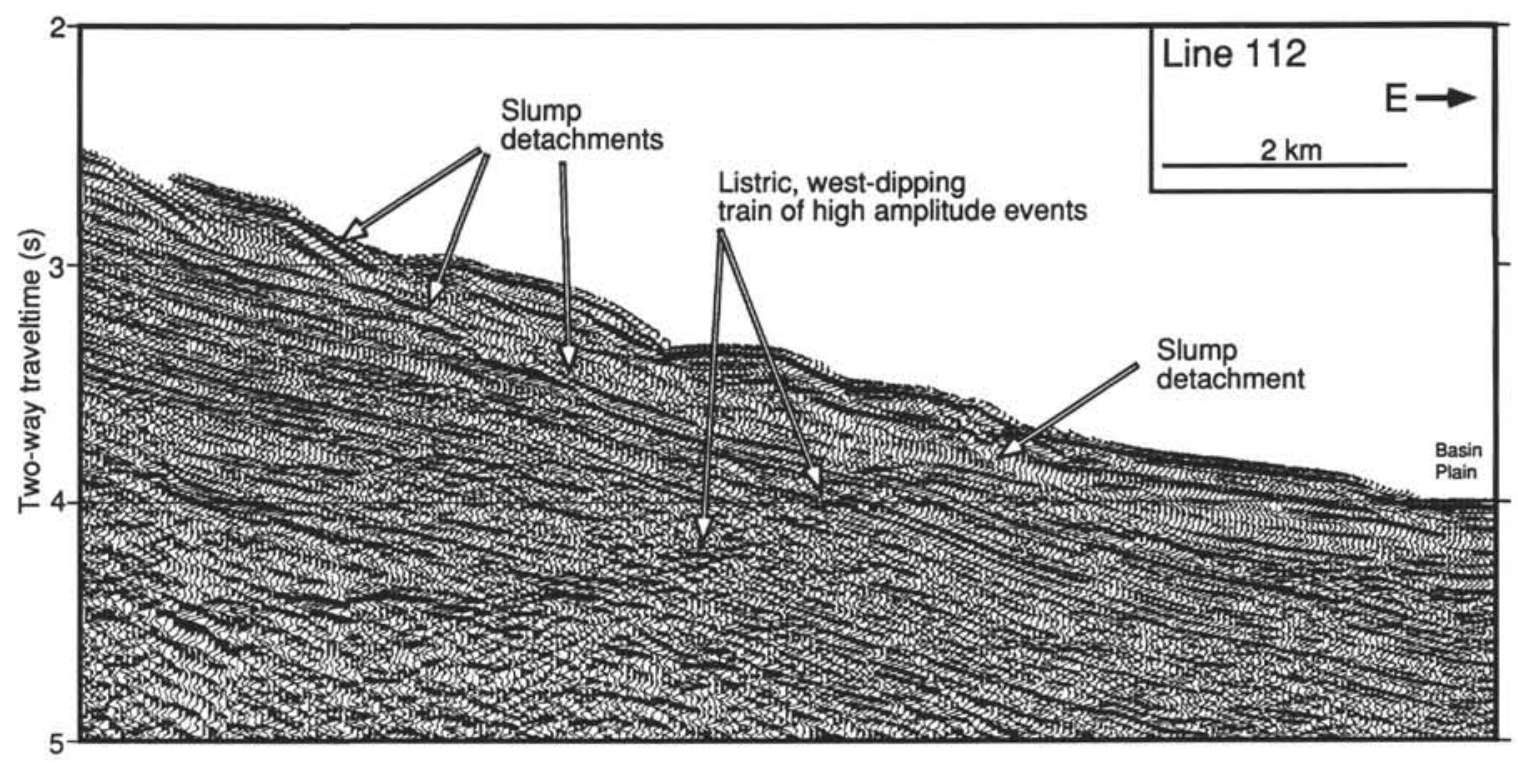

Figure 11. Migrated seismic data from line 112 show that one major sedimentary process that contributed basin fill is slumping of material from the west flank of the basin, as indicated by irregular topography in this seismic line and by the abundance of chaotically reflective or poorly reflective bodies in the basin. Location shown in Figure IB. 


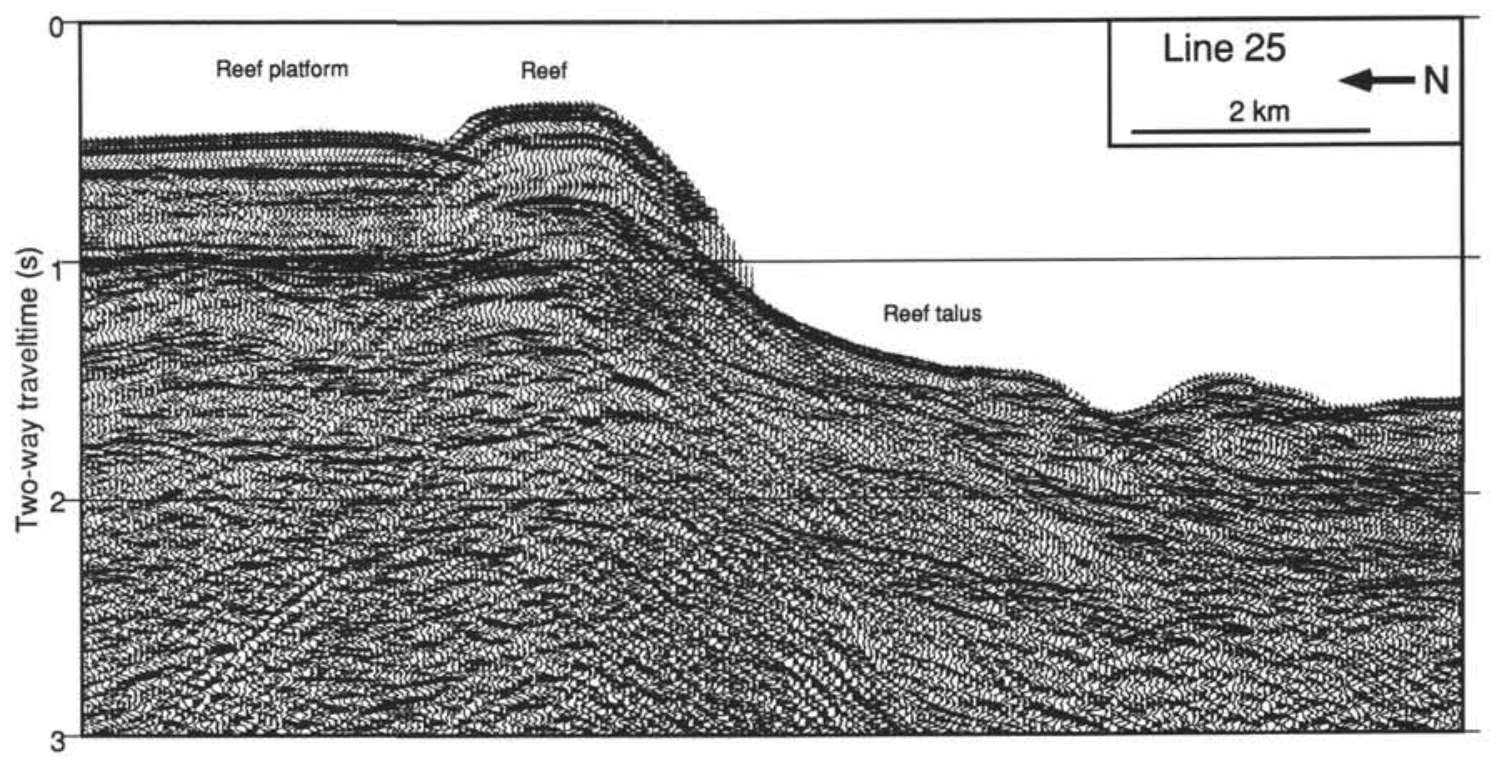

Figure 12. Migrated seismic data from line 25 show a submerged reef platform that parallels the coast of Espiritu Santo Island. Location shown in Figure IB.

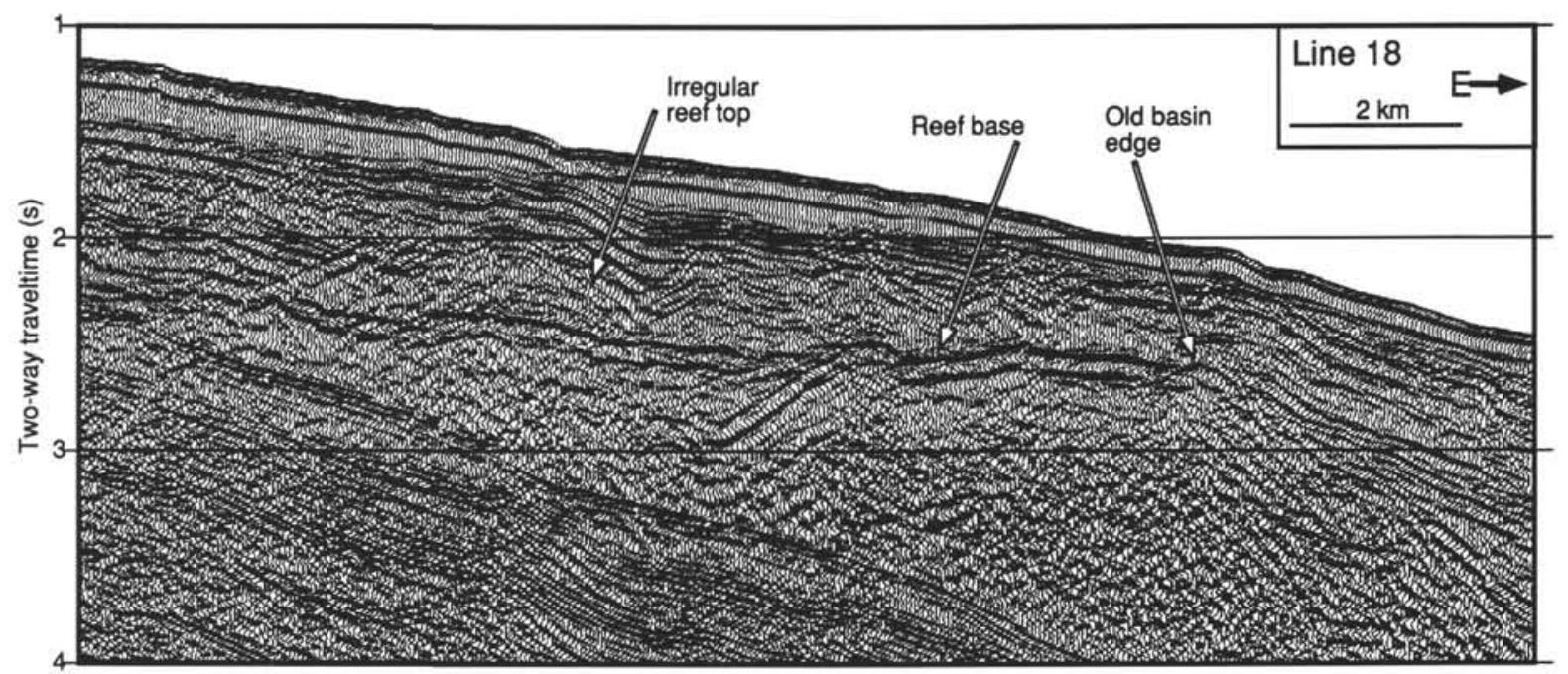

Figure 13. Migrated seismic data from line 18 show a suspected buried reef northeast of Espiritu Santo Island. Location shown in Figure IB.

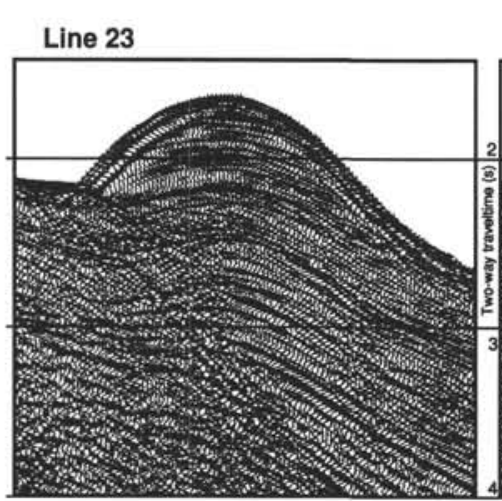

Stacked

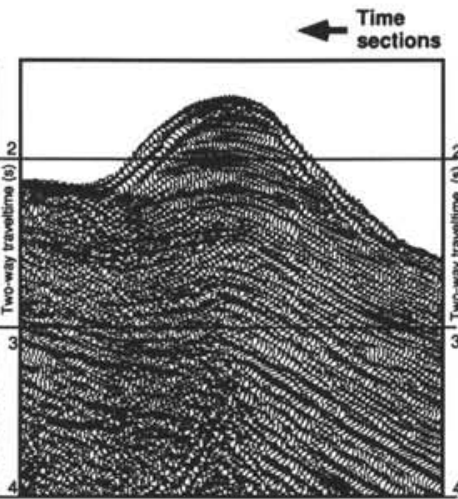

Migrated

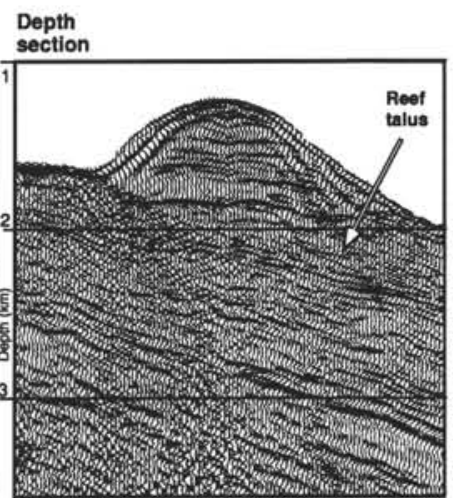

Depth converted

Figure 14. Three stages in the processing of seismic data from line 23 across an apparent faulted fold that is more likely to be the product of velocity pull up beneath a surficial reef. Location shown in Figure 1B. 